ДЕГТЯРЬОВА С.В.

\title{
ДО ХАРАКТЕРИСТИКИ ЗАГАЛЬНОДЕРЖАВНИХ СУБ'ЄКТІВ ДЕРЖАВНОГО РЕГУЛЮВАННЯ В АГРОПРОМИСЛОВІЙ СФЕРІ
}

У статті на основі аналізу наукових поглядів вчених та норм чинного законодавства України визначено та надано характеристику загальнодержавним суб'єктам державного регулювання в агропромисловій сфері. Доведено, що через регулюючу діяльність окреслених у статті суб'єктів, по-перше, визначаються вектори подальшого розвитку агропромислової сфери України, по-друге, створюються законодавчі, політичні та економічні засади для функціонування агропромислової сфери, по-третє, визначаються засади для діяльності спеціалізованих суб'єктів державного регулювання в агропромисловій сфері. 3'ясовано, що серед найважливіших ознак указу Президента як нормативно-правового акта підзаконного характеру є те, що він: характеризується багатоаспектністю й об'ємністю регулювання суспільних відносин залежно від масштабності функцій і повноважень президента; посідає пріоритетне місце в ієрархії підзаконних нормативних актів; відповідає конституції та іншим законам держави; сполучає одноособовий порядок ухвалення 3 колегіальністю підготовки, попереднього розгляду, посвідчення та відповідальності за виконання; $є$ загальнообов'язковим на всій території країни. Наголошено, що в рамках державного регулювання в агропромисловій сфері Президент України та Кабінет Міністрів України є досить універсальними суб'єктами державного регулювання в досліджуваній сфері суспільних відносин. Їх ключове призначення полягає в кількох важливих аспектах. 3 одного боку, вони наділені всією необхідною сукупністю повноважень для розробки та прийняття підзаконних нормативно-правових актів, норми яких спрямовані на врегулювання правовідносин у цій сфері. Такими актами, наприклад, можуть бути Положення про діяльність відповідного державного органу, Порядки видачі дозволів, ліценцій на ведення господарської діяльності в агропромисловій сфері тощо. 3 іншого боку, і Президента, і Кабінет Міністрів України також варто зарахувати до тих органів державної влади, які відповідають за формування та реалізацію державної політики в агропромисловій сфері.

Ключові слова: суб'єкт, загальнодержавні суб'єкти, державне регулювання, ВРУ, КМУ, Президент України, агропромислова сфера.

The article, based on the analysis of scientific views of scientists and norms of the current legislation of Ukraine, defines and characterizes the state-wide subjects of state regulation in the agro-industrial sphere. It is proved that due to the regulatory activity of the entities outlined in the article: first, the vectors of further development of the agro-industrial sphere of Ukraine are determined; secondly, the legislative, political and economic foundations for the functioning of the agro-industrial sector are being created; thirdly, the bases for the activities of specialized entities of state regulation in the agro-industrial sphere are determined. It has been found that among the most important features of the Decree, the President as a subordinate legal act is that he: is characterized by the multidimensional and voluminous regulation of social relations depending on the magnitude of the functions and powers of the President; takes a priority place in the hierarchy of by-laws; consistent with the constitution and other laws of the state; combines the single-person approval procedure with the collegiality of preparation, preliminary review, certification and responsibility for implementation; is mandatory throughout the country. It is emphasized that within the framework of state regulation in the agro-indus-

(C) ДЕГТЯРЬОВА С.В. - кандидат юридичних наук, докторант (Харківський національний університет внутрішніх справ) 
trial sphere the President of Ukraine and the Cabinet of Ministers of Ukraine are rather universal subjects of state regulation in the researched sphere of public relations. Their key purpose lies in several important aspects. On the one hand, they are endowed with all the necessary set of powers for the development and adoption of by-laws, the norms of which are aimed at regulating legal relations in this field. Such acts, for example, could be: Regulations on the activity of the relevant state body; Procedures for issuing permits, licenses for conducting business activities in the agro-industrial sphere; etc. On the other hand, both the President and the Cabinet of Ministers of Ukraine should also be referred to those bodies of state power responsible for the formation and implementation of state policy in the agro-industrial sphere.

Key words: subject, national subjects, state regulation, VRU, CMU, President of Ukraine, agro-industrial sphere.

Вступ. Система суб’єктів державного регулювання в агропромисловій сфері представлена чималою кількістю органів державної влади, кожен з яких виконує власні специфічні функції в цій сфері. Розглядати зміст, сутність та призначення діяльності таких органів у цій сфері суспільних відносин найбільш доцільно відповідно до їх поділу на загальнодержавні та спеціалізовані. На жаль, рамки представленого наукового дослідження не дають змогу розкрити зміст та призначення всіх суб'єктів, а тому ми приділимо увагу лише загальнодержавним суб'єктам державного регулювання в агропромисловій сфері, адже саме вони визначають «вектор» державного регулювання, його найбільш важливі пріоритети тощо. На нашу думку, ці суб'єкти «відповідають»: а) за створення законодавства в агропромисловій сфері; б) формування та реалізацію державної політики в досліджуваній сфері.

Окремих суб'єктів державного регулювання в агропромисловій сфері у своїх наукових дослідженнях розглядали М.О. Кальніцька, О.Р. Заяць, Г.В. Осипова, О.Ю. Прокопенко, А.П. Мукшименко, Н.М. Оніщенко, М.Ю. Покальчук, І.С. Окунєв, О.О. Тертичний, Т.М. Куценко, Л.Г. Макарова, О.В. Петришин, С.П. Погребняк, В.С. Смородинський та багато інших. Однак більшість науковців розглядали цих суб'єктів лише поверхнево, не здійснюючи комплексний аналіз.

Постановка завдання. Саме тому мета статті - надати характеристику загально-державним суб'єктам державного регулювання в агропромисловій сфері.

Результати дослідження. Переходячи безпосередньо до розгляду конкретних загальнодержавних суб'єктів державного регулювання перш за все варто приділити увагу Верховній Раді України (далі - ВРУ). ВРУ є парламентом України і єдиним органом законодавчої влади, що увібрала в себе світовий досвід парламентаризму. Парламентаризм не треба пов'язувати з якимись конкретними формами державного правління. У кожній країні світу конкретні його форми визначаються історично. Парламент - представницький виборний і вищий колегіальний орган державної влади, який функціонує в умовах демократичного управління і має свої повноваження у сфері законотворчості [1, с. 138; 2, с. 5]. До основних ознак парламенту зараховують такі : це колегіальний орган, що складається з групи депутатів, чисельність яких залежить від його представницького характеру; постійно діючий орган; це загальнодержавний орган; повинен мати легітимний характер; є органом загальної компетенції; поширює свої повноваження на територію всієї держави; формується шляхом виборів. Верховна Рада $є$ колегіальним органом. Це означає, що усі питання своєї компетенції Верховна Рада вирішує спільно шляхом голосування. У Конституції України при вирішенні різних питань компетенції Верховної Ради закріплюється різний порядок голосування і набрання різної кількості голосів від 1/3 до $3 / 4$ ії конституційного складу [2, с. 5]. В.С. Чиркін справедливо підкреслює, що сучасний парламент - це вищий орган народного представництва, який відображає суверенну волю народу, покликаний регулювати найважливіші суспільні відносини, в основному шляхом прийняття законів, який здійснює контроль за діяльністю органів виконавчої влади і вищих посадових осіб. Парламент володіє багатьма іншими повноваженнями. Він формує інші вищі органи держави, ратифікує міжнародні договори та ін. [3, с. 236; 4].

Відповідно до ст. 85 Основного Закону, до повноважень Верховної Ради України належать: 1) внесення змін до Конституції України в межах і порядку, передбачених розділом ХІІІ цієї Конституції; 2) призначення Всеукраїнського референдуму з питань, визначених Основним Законом нашої держави; 3) прийняття законів; 4) затвердження Державного бюджету України та внесення змін до нього, контроль за виконанням Державного бюджету України, прийняття рішення щодо звіту про його виконання; 5) визначення засад внутрішньої і зовнішньої політики, 
реалізації стратегічного курсу держави на набуття повноправного членства України в Свропейському Союзі та Організації Північноатлантичного договору; 6) затвердження загальнодержавних програм економічного, науково-технічного, соціального, національно-культурного розвитку, охорони довкілля; 7) призначення виборів Президента України у строки, передбачені цією Конституцією; 8) заслуховування щорічних та позачергових послань Президента України про внутрішнє і зовнішнє становище України; 9) оголошення за поданням Президента України стану війни і укладення миру, схвалення рішення Президента України про використання Збройних сил України та інших військових формувань у разі збройної агресії проти України; 10) усунення Президента України з поста в порядку особливої процедури (імпічменту), встановленому ст. 111 Конституції; 11) розгляд і прийняття рішення щодо схвалення Програми діяльності Кабінету Міністрів України тощо [5].

Множинність повноважень українського парламенту не суперечить його правовій природі як єдиного органу законодавчої влади в Україні, оскільки він подібно до інших державних органів у властивих йому формах виконує низку важливих завдань державної влади в різних сферах життєдіяльності суспільства - економічній, політичній, соціальній, культурній та ін. 3-поміж великого обсягу компетенції українського парламенту найголовнішою є законодавча, яка, по суті, підкреслила його функціональне призначення як єдиного органу законодавчої влади в Україні [6]. Законодавча компетенція Верховної Ради України зумовлює винятково важливе значення парламенту в конституційній системі державних органів. Основний зміст законодавчої компетенції Верховної Ради України - це її права та обов'язки у сфері розробки, прийняття Конституції і законів України та інших правових актів, внесення до них змін та доповнень, визнання їх такими, що втратили чинність, а також надання згоди на обов'язковість міжнародних договорів на території України. Доктрина конституційного розвитку нашої держави виокремлює пріоритетне право українського народу приймати Конституцію України, проте і Верховна Рада України не позбавлена такого права [6].

Наступний суб'єкт, якому ми приділимо увагу в рамках окресленої проблематики, - Президент України. Президент - це одноособовий глава держави або глава держави і виконавчої влади в країнах із республіканською формою правління, який представляє державу в міжнародних відносинах. За Конституцією України, Президент України - це одноособовий глава держави, який представляє державу в міжнародних відносинах і $€$ гарантом державного суверенітету. Основні функції і повноваження Президента визначаються Конституцією України, за якою Президент $є$ главою держави і виступає від іiї імені. Він є гарантом державного суверенітету, територіальної цілісності України, додержання Конституції, прав і свобод людини і громадянина. Президент забезпечує державну незалежність, національну безпеку і правонаступництво держави [7].

Відповідно до Конституції Президент України наділений цілою низкою повноважень, для реалізації яких видає підзаконні нормативно-правові акти у вигляді указів Президента. Так, О.Ф. Скакун зауважує, що Указ Президента України - це підзаконний акт-документ, що ухвалюється на підставі та на виконання закону з найважливіших питань життя суспільства та держави 3 метою сприяння ефективній реалізації закону. При цьому вчена серед найважливіших ознак вищенаведеного нормативно-правового акта підзаконного характеру виокремлює те, що він: характеризується багатоаспектністю й об'ємністю регулювання суспільних відносин залежно від масштабності функцій і повноважень президента; посідає пріоритетне місце в ієрархії підзаконних нормативних актів; відповідає конституції та іншим законам держави; сполучає одноособовий порядок ухвалення з колегіальністю підготовки, попереднього розгляду, посвідчення та відповідальності за виконання; є загальнообов'язковим на всій території країни [8, с. 480].

Не можна оминути увагою Кабінет Міністрів України, який є вищим органом виконавчої влади, якому підпорядковуються міністерства, комітети, центральні органи, наділені спеціальним статусом. Кабінету Міністрів належить основна роль в управлінні економікою, забезпеченні реалізації законів, постанов та інших законодавчих актів [9, с. 118]. Відповідно до Закону України «Про Кабінет Міністрів України» від 27 лютого 2014 року, до основних завдань КМУ належать: 1) забезпечення державного суверенітету та економічної самостійності України, здійснення внутрішньої та зовнішньої політики держави, виконання Конституції та законів України, актів Президента України; 2) вжиття заходів щодо забезпечення прав і свобод людини та громадянина, створення сприятливих умов для вільного і всебічного розвитку особистості; 3) забезпечення проведення бюджетної, фінансової, цінової, інвестиційної, в тому числі амортизаційної, податкової, структурно-галузевої політики; політики у сферах праці та зайнятості населення, соціального захисту, охорони здоров'я, освіти, науки і культури, охорони природи, екологічної безпеки 
і природокористування; 4) розроблення і виконання загальнодержавних програм економічного, науково-технічного, соціального, культурного розвитку, охорони довкілля, а також розроблення, затвердження і виконання інших державних цільових програм; 5) забезпечення розвитку і державної підтримки науково-технічного та інноваційного потенціалу держави; 6) забезпечення рівних умов для розвитку всіх форм власності; здійснення управління об'єктами державної власності відповідно до закону; 7) здійснення заходів щодо забезпечення обороноздатності та національної безпеки України, громадського порядку, боротьби із злочинністю, ліквідації наслідків надзвичайних ситуацій; 8) організація і забезпечення провадження зовнішньоекономічної діяльності, митної справи; 9) спрямування та координація роботи міністерств, інших органів виконавчої влади, здійснення контролю за їх діяльністю [10].

До ключових функцій КМУ належать: 1) політична - полягає в здійсненні внутрішньої та зовнішньої політики держави, засади якої визначаються парламентом; 2) економічна - полягає в забезпеченні проведення фінансової, цінової, інвестиційної і податкової політики, управління об'єктами державної власності; 3) бюджетна - полягає в розробці проекту основних напрямів бюджетної політики на наступний рік; 4) соціальна - полягає в реалізації політики у сфері праці й зайнятості населення, соціального захисту, розробці і здійсненні загальнодержавних програм соціального розвитку України; 5) гуманітарна - полягає в реалізації політики у сфері освіти, науки, культури, розробці та здійсненні загальнодержавних програм науково-технічного і культурного розвитку; тощо [9, с. 118].

У рамках представленої проблематики варто також зазначити, що Кабінет Міністрів України в межах своєї компетенції видає постанови і розпорядження, які є обов'язковими до виконання [6]. Так, постанови - це нормативно-правові акти, що приймаються на виконання Конституції та законів України з найбільш важливих питань компетенції Кабінету Міністрів України. Постанови уряду, крім постанов, що містять інформацію з обмеженим доступом, набирають чинності $з$ дня їх опублікування в «Офіційному віснику України», якщо інше не передбачено самими постановами, але не раніше дня їх опублікування. Правові акти уряду також оприлюднюються шляхом їх розміщення на офіційному вебсайті Кабінету Міністрів України [6]. Своєю чергою, розпорядження - це внутрішні організаційно-розпорядчі індивідуально-владні правові акти, які адресуються органам чи посадовим особам, підпорядкованим уряду. Розпорядження Кабінету Міністрів України набирають чинності з моменту їх прийняття, якщо цими розпорядженнями не встановлено пізніший термін набрання ними чинності [6]. Д.М. Бахрах слушно зазначає, що акти Кабінету Міністрів характеризуються певними ознаками, які дають їм змогу нам говорити про них як про окремий вид юридичних актів: акти Кабінету Міністрів - це виконавчі, підзаконні акти, які деталізують і конкретизують окремі положення законів і указів Президента; серед актів Кабінету Міністрів є багато актів міжгалузевого, загальнорегламентаційного характеру, які регулюють різноманітні сфери і галузі життя країни; акти Кабінету Міністрів посідають найвищу сходинку в ієрархії актів виконавчої влади і виступають фундаментальною основою для відомчих нормативних актів; акти Кабінету Міністрів обов'язкові для виконання на всій території країни; виконання актів Кабінету Міністрів забезпечуються системою органів державної влади [11].

Таким чином, у рамках державного регулювання в агропромисловій сфері Президент України та Кабінет Міністрів України є досить універсальними суб'єктами державного регулювання в досліджуваній сфері суспільних відносин. Іх ключове призначення полягає в кількох важливих аспектах. 3 одного боку, вони наділені всією необхідною сукупністю повноважень для розробки та прийняття підзаконних нормативно-правових актів, норми яких спрямовані на врегулювання правовідносин у цій сфері. Такими актами, наприклад, можуть бути Положення про діяльність відповідного державного органу, Порядки видачі дозволів, ліценцій на ведення господарської діяльності в агропромисловій сфері тощо. 3 іншого боку, і Президента, і КМУ також варто зарахувати до тих органів державної влади, які відповідають за формування та реалізацію державної політики в агропромисловій сфері.

Висновки. Отже, завершуючи представлене наукове дослідження, варто підсумувати, що діяльність загальнодержавних суб'єктів державного регулювання в агропромисловій сфері спрямована, перш за все, на загальне регулювання досліджуваної сфери, тобто на створення законодавчої бази, а також на формування та реалізацію державної політики. Через регулюючу діяльність окреслених у статті суб'єктів, по-перше, визначаються вектори подальшого розвитку агропромислової сфери України, по-друге, створюються законодавчі, політичні та економічні засади для функціонування агропромислової сфери, по-третє, визначаються засади для діяльності спеціалізованих суб'єктів державного регулювання в агропромисловій сфері. 


\title{
Список використаних джерел:
}

1. Верховна Рада України: інформаційний довідник / Авт.-упор.: В.О. Зайчук, Ю.В. Ясенчук, А.В. Пивовар та ін. Вип. 3. Київ : Парламентське вид-во, 2006. 264 с.

2. Гошовська В.А. Парламентаризм в Україні. Державно-управлінські механізми реалізації функцій законодавчої влади : навч.-метод. матеріали / В.А. Гошовська, Л.А. Пашко, К.Ф. Задоя. Київ : НАДУ, 2013. 48 с.

3. Чиркин В.Е. Конституционное право зарубежных стран : учебник. Москва : Юристъ, 1999. $599 \mathrm{c}$.

4. Александров О.А. Конституційно-правові засади статусу народного депутата України : дис. ... канд. юрид. наук : 12.00.02 / Київ. нац. ун-т ім. Т. Шевченка. Київ, 2009. 255 арк.

5. Конституція України від 28.06.1996 р. № 254к/96-BP. URL: https://zakon.rada.gov.ua/ laws/show/254к/96-вр/conv

6. Шаптала Н.К., Задорожня Г.В. Конституційне право України : навч. посібник. Дніпропетровськ : ТОВ «ЛізуновПрес», 2012. 472 с.

7. Денисюк С.Ф. Громадський контроль за правоохоронною діяльністю в Україні: адміністративно-правові засади : дис ... д-ра юрид. наук : 12.00.07. Дніпропетровськ : Б.в., 2010. 393 с.

8. Скакун О.Ф. Теорія держави і права (Енциклопедичний курс) : підручник; видання 2-е, перероблене і доповнене. Харків : Еспада, 2009. 752 с.

9. Калетнік Г.М., Мазур А.Г., Кубай О.Г. Державне регулювання економіки : Навчальний посібник. Київ : «Хай-Тек Прес», 2011. 428 с.

10. Про Кабінет Міністрів України : Закон України від 27.02.2014 р. № 794-VII.

11. Чикурлій С.О. Конституційно-правовий статус органів виконавчої влади України : дис. ... канд. юрид. наук : 12.00.02 / Інститут законодавства Верховної Ради України. Київ, 2008. 214 арк.

ЖУРАВЕЛЬ Я.В.

\section{СПІВВІДНОШЕННЯ ПОНЯТЬ «ФУНКЦЇ̈», «КОМПЕТЕНЦІЯ», «ПОВНОВАЖЕННЯ» В ДЕРЖАВНОМУ УПРАВЛІННІ}

\begin{abstract}
У статті розкрито сутність та особливості співвідношення понять «функції», «компетенція», «повноваження» в державному управлінні. 3'ясовано, що функції органів виконавчої влади визначаються функціями державного управління і фактично $є$ їхньою складовою частиною, головною метою органів виконавчої влади $\epsilon$ якісна реалізація завдань і функцій державного управління, які націлені на виконання чинних нормативно-правових актів та загалом державної стратегії розвитку країни. Визначено, що функції поділяються на загальні та спеціальні, внутрішні і зовнішні, загальні та специфічні. 3'ясовано, що вчені-адміністративісти до функцій виконавчої влади відносять регулятивну, контрольно-наглядову, правоохоронну, 3 урахуванням яких визначаються відповідні завдання щодо їх реалізації. Проаналізовано концептуальні погляди науковців щодо сутності понять «функції», «компетенція», «повноваження», особливостей їх співвідношення. Теоретично обгрунтовано, що функції в кількох органів можуть бути ті ж самі, а конкретні завдання та повноваження щодо їх реалізації - різними; вирішення питання про функції органу значною мірою зумовлюється проблемою надання йому конкретних владних повноважень; для успішної реалізації функцій державного управління юридична наука повинна мати відповідний інструментарій пізнання: розвинуту систему категорій і понять - понятійний апарат, що визначається предметом цієї науки; для
\end{abstract}

() ЖУРАВЕЛЬ Я.В. - кандидат юридичних наук, доцент, декан юридичного факультету (Академія праці, соціальних відносин і туризму) 